\title{
CZARNY ROMANTYZM \\ Augusta Antoniego Jakubowskiego
}

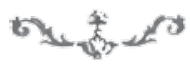

Nie ma ojczyzny, gdzie nie ma wolności. Słońce nie wschodzi dla niewolnika, ziemia nie stroi się dla niego; a jego pokarm zmienia się w truciznę.

August Antoni Jakubowski, Odezwa Komitetu Polskiego w Paryżu do polskich emigrantów ${ }^{1}$

\section{ŻYCIE, DZIEŁO, CZARNY ROMANTYZM}

U

TWORY PRZYNALEŻNE do nurtu czarnego romantyzmu w rozmaity sposób są powiązane z biografią ich twórców. Można przyjąć, iż najlepsze literacko efekty osiągają ci pisarze, którzy umiejętnie łączą literacką konwencję, opartą na wzorcach wczesnoromantycznych podpatrzonych za granicą (George Gordon Byron, Walter Scott, Thomas Moore, powieść gotycka, młody Victor Hugo), z głębokim uzewnętrznieniem wstrząsowych doznań egzystencjalnych, które po jaspersowsku moglibyśmy nazwać sytuacjami granicznymi. Tak jest w Marii Antoniego Malczewskiego, Zamku kaniowskim Seweryna Goszczyńskiego czy w Agaj-Hanie Zygmunta Krasińskiego.

O wiele mniej udane - z estetycznego punktu widzenia - wydadzą nam się teksty wprawdzie zakorzenione w imaginacji autora, lecz zupełnie zależne od konwencji, takie jak powiastki i powieści gotyckie młodego Krasińskiego,

1 A.A. Jakubowski, Odezwa Komitetu Polskiego w Paryżu do polskich emigrantów, w: tegoż, Wspomnienia polskiego wygnanca / The Remembrances of a Polish Exile, wydanie polsko-angielskie, przekład, wstęp, redakcja tomu J. Ławski i P. Oczko, Białystok 2013, s. 100. 
poezje wykorzystujące temat ukraiński: Józefa Bohdana Zaleskiego, Aleksandra Grozy czy Tadeusza Łady-Zabłockiego. Wreszcie nie zawsze szczęśliwe efekty uzyskują pisarze dążący do pewnej dozy czarnoromantycznego „autentyzmu”. O dziwo, to ich tekstom zarzuca się konwencjonalizm, epigoństwo, chaos kompozycyjny i grandilokwencję.

Tak właśnie stało się, nie do końca słusznie, z ocenami Lesława Romana Zmorskiego czy utworami twórców Cyganerii Warszawskiej, którzy wprost nawiązywali do wczesnego „czarnego romantyzmu”, by przypomnieć artykuł [Malczewski zapomniany] Wiktoryna Zielińskiego, poezje Seweryna Filleborna czy Ojca Hilarego Włodzimierza Wolskiego ${ }^{2}$.

Jak trudno o jednoznaczne wnioski w kwestii związków biografii (lub egzystencji) z tekstem, pokazuje przykład arcydzieła z 1825 roku ustanawiającego w polskim romantyzmie cały nurt - Marii Malczewskiego. Z jednej strony zarzucano jej hiperbajronizm, z drugiej dopatrywano się w niej najgłębszych wyrazów przeżyć, traum, klęsk pisarza, uformowanych w liryczny strumień poematu. W tym rozdwojeniu ocen są zgodne krytyka dziewiętnastowieczna i historia literatury z przełomu XX i XXI wieku. W 1912 roku Władysław Dropiowski tak ujmował podmiotowy i obiektywny charakter liryzmu Marii:

Istotnie melancholia, skutek indywidualności poety i charakteru tła lokalnego, jest najwybitniejszą cechą poematu. Liryzm, wypływający bezwiednie i niewidocznie, łączy się tu w jednolitą całość z opisowością, osobisty nastrój poety wsiąka niejako w fabułę, przesyca ją sobą, tworzy jak gdyby podkład muzyczny, który oddziaływa niesłychanie na mało nawet wrażliwego czytelnika. Wszystko dostraja się tu do jednego tonu: obrazy natury, postaci działające, ich słowa, uczucia i bieg wypadków, dość częste w końcu refleksje poety, pełne bólu, żalu, tęsknoty. ${ }^{3}$

Postrzegając Malczewskiego inaczej, bo w świetle mitu napoleońskiego, konkluduje jednak Adam Mickiewicz w Prelekcjach paryskich, iż:

Malczewski, żołnierz wojsk narodowych z czasów cesarstwa, po upadku Napoleona długo podróżował za granicą; umarł w Warszawie. Podobnie jak lord Byron, szukał wrażeń w obcych krajach, w Szwajcarii i we Włoszech; w swym życiu tułaczym czytał autorów cudzoziemskich; szczególnie, jak się zdaje, przejął się poezjami Byrona. ${ }^{4}$

Równie wyraziste są opinie badaczy późniejszych, którzy pomimo różnic $\mathrm{w}$ ujęciu proporcji między konwencją a egzystencją, nigdy nie ważą się na sądy

2 Zob. S. Kawyn, Wstęp, w: Cyganeria warszawska, oprac. i wybór S. Kawyn, Wrocław 2004.

3 W. Dropiowski, Wstęp, w: A. Malczewski, Maria. Powieść ukraińska, oprac. W. Dropiowski, Brody 1902, s. 15.

4 A. Mickiewicz, Wykład XXX, w: tegoż, Dzieła. Wydanie Rocznicowe, t. 9: Literatura słowiańska. Kurs drugi, przeł. L. Płoszewski, oprac. J. Maślanka, Warszawa 1997, s. 381. 
deprecjonujące artystyczną wielkość Marii. Zdaniem Aliny Kowalczykowej, Maria to forpoczta mistycznej fazy romantyzmu:

Przede wszystkim jednak fascynujące wydaje się stwierdzenie, że oto u progu naszego romantyzmu istniała już możliwość wprowadzenia go w krąg nurtu mistycznego, wyrastającego z najświetniejszej, drezdeńskiej sztuki - czyli wprowadzenia takich niepokojących problemów, jakie pojawią się dopiero w latach czterdziestych w twórczości na przykład Juliusza Słowackiego. ${ }^{5}$

Zupełnie z innej perspektywy postrzega tę kwestię badaczka czarnoromantycznej estetyki, Halina Krukowska, przekonując, iż: „Życie Malczewskiego miało więc w sobie coś głęboko smutnego, przygnębiającego i tragicznego" . Dlatego - twierdzi uczona - „Nadrzędnym tematem Marii jest Tajemnica Metafizyczna w najgłębszym, ontologicznym sensie tego słowa”. Jak się wydaje, od „Tajemnicy” niedaleko do „mistyki” - tu zgodne byłyby obie badaczki.

Kwestia zdaje się trudna, jeśli nie niemożliwa do rozstrzygnięcia. Oceny literackiej wartości dzieł są bowiem (i będą...) różne. Na przykład w biografii Zmorskiego trudno znaleźć aż tak dojmujące przeżycia, które jednoznacznie kazałyby przekuwać egzystencjalne treści w estetykę pesymistycznego Lesława ${ }^{8}$. W poemacie dopatrywano się już w XIX wieku albo tromtadracji i epigoństwa, jak czynił to Marceli Motty, autor pamfletu na Lesława9. Albo chciano w nim widzieć dzieło na miarę i na nutę liryki takiego „nihilisty”, jak Giacomo Leopardi, albo poety-pesymisty w stylu Percy'ego Shelleya czy filozofa Philippa Mainländera. Adam Rzążewski przekonywał, wspominając zmarłego pisarza:

Zmorski był człowiekiem, jak to już tylokrotnie powiedzianym było, nadzwyczaj zdolnym: sądząc z jego młodzieńczych porywów, współcześni, słusznie mu wielką rokowali sławę i widzieli go w rzędzie największych naszych geniuszów: ale czy to wskutek tego, że w młodości nie odebrał od razu gruntownego ukształcenia; czy też może zbytnia twórczość, objawiająca się zaraz w pierwszych latach życia: odciągnęła go od

5 A. Kowalczykowa, Antoni Malczewski i Drezno, w: tejże, Wokół romantyzmu. Estetyka - polityka - historia, red. i oprac. A. Janicka, G. Kowalski, Białystok 2014, s. 149.

6 H. Krukowska, Ciemna strona istnienia w romantycznym poemacie Malczewskiego, w: A. Malczewski, Maria. Powieść ukraińska, wstęp H. Krukowska i J. Ławski, Białystok 2002, s. 9.

7 Tamże, s. 14.

8 Podkreśla to Edward Pieścikowski: „Wreszcie dobrowolne ubóstwo jako narzucony sobie styl życia: «chodzili umyślnie brudno i ubogo, zgiełk wielki robili nawet po ulicach» - wspomina Julian Bartoszewicz. Rzeczywiście nędza Zmorskiego wygląda podejrzanie, skoro zwierzył się Lenartowiczowi, iż ojciec jego «dusił pieniądze» $\mathrm{i}$ «na fanty» pożyczał" (E. Pieścikowski, Poeta-tułacz. Biografia literacka Romana Zmorskiego, Poznań 1964, s. 14-15).

9 Wojtuś [M. Motty], De omnibus rebus et quibusdam aliis. List XXXVII, „Dziennik Poznański” 1866, nr 118, s. 141. 
twardej i usilnej pracy; ale nie stworzył nam nic takiego, co by w zupełności godnym było jego talentu. Zbytni zapał młodzieńczy, o którym powiadamy, że wyszumi z czasem, w nim nie wyszumiał nigdy i słusznie też powiada J.I. Kraszewski, ten wielki znawca serca ludzkiego, w liście wyżej wspomnianym: „był w nim poeta, był zacny i szlachetny młodzian, ale z młodziana nigdy nie wyrósł na męża”. Te słów kilka doskonale charakteryzują zmarłego. ${ }^{10}$

Warto raz jeszcze podkreślić, że dzieła czarnoromantyczne są ekspresją i zarazem syntezą: wyobraźni poety, znanych i przekształconych konwencji literackich (także tych poprzedzających romantyzm, jak osjanizm, gotycyzm, libertynizm, poezja nocy i grobów) oraz w każdym przypadku odmiennych doświadczeń egzystencjalnych. U Malczewskiego zmagania z losem to praktycznie całe życie, które zakończą: śmiertelna choroba (zapewne rak), niezwykły związek z Zofią Rucińską i zupełna towarzyska oraz finansowa ruina.

Nic dziwnego, że do biografii Malczewskiego nie nawiązał ani w ogóle, ani w szczególe jego nieślubny syn, August Antoni Jakubowski (ok. 1816-1837), publikując w Ameryce esej-sylwę The Remembrances of a Polish Exile (Wspomnienia polskiego wygnańca, Filadelfia 1835), w którym pomieścił znaczący passus o Malczewskim jako jedynym godnym rywalu Mickiewicza, zaświadczając ów sąd przekładami czy raczej parafrazami dwóch fragmentów Marii (ustęp V i XI z Pieśni I). Co więcej, Jakubowski nie napisał, że ów świetny rywal wieszcza, to jego ojciec.

Życie Jakubowskiego biegło osobliwym torem: był nieślubnym synem Antoniego Malczewskiego. Jak się przyjmuje, urodził się między 1814 a 1816 rokiem (na grobie poety, znajdującym się do dziś w Northampton w Stanach Zjednoczonych, wyryto datę śmierci: 24 kwietnia 1837 roku i wiek: 21 lat) ${ }^{11}$. Nie jest $\mathrm{w}$ chwili obecnej znane nazwisko jego matki ${ }^{12}$. Młody poeta kończył to samo co ojciec Liceum Krzemienieckie. W czasie nauki odezwał się w nim duch patriotyczny i jako nastoletni chłopiec miał porzucić szkołę, by dołączyć do powstańców listopadowych w Królestwie Polskim. Po powstaniu powrócił do Galicji, gdzie schroniło się wielu Polaków. Tu w nieznanych okolicznościach, zapewne związanych z działaniami konspiracyjnymi i tak zwaną partyzantką

A. Rzążewski, Roman Zmorski. Kilka słów poświęconych pamięci zmarłego w dniu 18 lutego 1867 roku poety, „Biblioteka Warszawska” 1868, t. 1, s. 24-59.

11 Zob. Aneks, w: A.A. Jakubowski, Wspomnienia..., s. 57 (fot. F. Zimnoch). Z informacji wyrytej na nagrobku wynika, że pisarz miałby urodzić się w 1816 roku. Rodzi to kolejne pytanie: czy to możliwe, by udział w powstaniu listopadowym wziął już jako czternastolatek?

12 Jak sugeruje Ewa Modzelewska, matką poety miałaby być Franciszka Lubomirska. Zob. E. Modzelewska, August Antoni Jakubowski. Poeta rozpaczy. Życie i twórczość, Kraków 2015. 
Zaliwskiego, został w roku 1833 aresztowany przez władze austriackie wraz z ponad dwustu innymi Polakami, stanowiącymi zagrożenie dla porządku politycznego w Europie. Początkowo więzieni w twierdzy Brünn (Brno) na Morawach, przeniesieni zostali następnie do Triestu, gdzie po śledztwie na podstawie porozumienia Rosji, Austrii i Prus w Münchengrätz postawiono ich przed wyborem - deportacja do Stanów Zjednoczonych Ameryki lub deportacja do Rosji, gdzie czekałby ich sąd, zesłanie. Około 235 osób wybrało deportację do Ameryki, licząc wcześniej, że przyjmie ich Francja, kraj uważany za „serce rewolucji i poglądów liberalnych"13. Ta jednak odmówiła przyjęcia wygnańców. W Ameryce Jakubowski, z pomocą prezbiterian skupionych wokół pastora Williama Buella Sprague’a, szybko się zaaklimatyzował, w ciągu roku nauczył się języka angielskiego, został nauczycielem języka francuskiego. Podjął jednak w 1836 roku niefortunną decyzję o podróży do Meksyku, gdzie osiadł jako oficer wojsk meksykańskich brat jego ojca, Konstanty Malczewski (Constantino Pablo Tarnava de Malquesci). Jakubowski nie nawiązała serdecznych kontaktów ze stryjem. W czasie trudnej podróży do Meksyku zapadł na ciężką chorobę, która sprawiła, iż był „zdefigurowany garbem na plecach"14. Po powrocie do Ameryki raz jeszcze podjął pracę nauczycielską, uwielbiany przez swoje uczennice. Z nieznanych powodów, które przybliżają tylko jego wiersze, popełnił 24 kwietnia 1837 roku samobójstwo w Northampton w stanie Massachusetts.

Tuż przed wyjazdem do Meksyku wydał Jakubowski pierwszą w Ameryce książkę zawierającą tłumaczenia poezji polskiej na język angielski: The Remembrances of a Polish Exile (1835) ${ }^{15}$. Pisał to dzieło, nie dysponując biblioteką z polskimi książkami. Jest to więc jakby przypomniana, niepełna, pisana z pamięci nie tylko historia literatury polskiej w zarysie, ale i kultury, a szczególnie dziewiętnastowiecznej historii Polski pod zaborami. Jakubowski wybrał nowoczesną formę niewielkiej, ale bogatej tematycznie książki, którą nazywać można esejem, a także sylwą, zbudowaną z następujących części: Dedykacja (wiersz To the Ladies of America), W.B. Sprague, Uwagi wstępne (wstęp pastora polecający dziełko amerykańskim czytelnikom), Przedmowa, Szkic o poezji polskiej, Historyczny szkic o oświacie w Polsce, Polscy kochankowie

13 A.A. Jakubowski, Przyczyny emigracji Polaków, w tegoż, Wspomnienia..., s. 95.

14 M. Rosienkiewicz, Wiadomość biograficzna o Jakubowskim, w: A.A. Jakubowski, Poezje, wydał z rękopisu i wstępem poprzedził J. Maślanka, Kraków 1973, s. 69.

15 Kwestia, gdzie ukazało się jej pierwsze wydanie, pozostaje jeszcze sporna - albo w Auburn, albo w Albany, albo w Filadelfii. Która z tych edycji była pierwsza, nie ma obecnie pewności. Wymieńmy te publikacje: Packard and Van Benthuysen, Albany 1835, 69 s.; Adam Waldie, Philadelphia 1835, 69 s.; Alen \& Lounsbury, Auburn, New York 1835, 72 s. 
(nowela), Przyczyny emigracji Polaków, Odezwa Komitetu Polskiego w Paryżu do polskich emigrantów (autentyczna odezwa z XIX wieku), Dodatek zawierajacy krótka wzmiankę o Ukrainie i Podolu. Całość była przeplatana tłumaczeniami dzieł polskich na język angielski, których dokonał Jakubowski ${ }^{16}$. Jest to, owszem, książka, której celem było przekazanie wiedzy o nieznanej Amerykanom kulturze polskiej. Miała więc cel popularyzatorski, doczekała się przynajmniej pięciu wydań i wznowień w dziewiętnastowiecznej Ameryce, wznowienia dwudziestowiecznego i licznych reprintów (print on demand). Raczej nie łączyła się jednak z pracą nauczycielską - zawierała treści zbyt odległe od tego, czego i program wymagał, i zalecały władze oświatowe. Do jej tonacji należy pesymizm autora, żywioł politycznej polemiki. Niewątpliwie można ją nazwać jednym z najbardziej niezwykłych owoców, jakie wydała misja edukacyjna Tadeusza Czackiego prowadzona w Liceum Krzemienieckim. Edukacja utrzymana była tu w duchu oświeceniowym i klasycystycznym. Oto wychowanek szkoły na wygnaniu w Ameryce spisał prawie z pamięci wiadomości o polskiej kulturze, historii, literaturze. Uczynił to tak dobrze, że książkę czytali zarówno opiekujący się polskimi emigrantami Amerykanie, jak i Polacy, którym aklimatyzacja nie przychodziła wcale łatwo. Książka była niemal w Polsce nieznana do 1930 roku, gdy równocześnie o Jakubowskim i jego dokonaniach przypomnieli Julian Krzyżanowski i Stanisław Pigon ${ }^{17}$. W 2013 roku przekład wydania z 1835 roku z Filadelfii wraz z tekstem angielskim ukazał się w Naukowej Serii Wydawniczej „Czarny Romantyzm” ${ }^{18}$.

Mamy oto sytuację niezwykłą - zapomniany w kraju „syn Malczewskiego”, niewątpliwie tak jak ojciec należący do ukraińskiego nurtu („szkoły”) w literaturze polskiej, publikuje dziełko będące jego własnym rozliczeniem z wygnańczym życiem, które, jak zaczęło się w sposób niezwykły, tak skończyło tragicznie aktem samobójczym. Od czasu odkrywczej publikacji jego Poezji przez

16 W książce pomieszczono tłumaczenia następujących dzieł polskich: Mickiewicza (Pierwiosnek, pieśń Gustawa z Dziadów, pieśń o Wilii z Konrada Wallenroda, parafraza fragmentów Ksiag narodu polskiego i pielgrzymstwa polskiego, drobny fragment wiersza Do Matki Polki wykorzystany jako motto), Malczewskiego (fragmenty dwa z Marii), wiersz Gdyby orłem być Maurycego Gosławskiego, Dziewczyna Juliana Korsaka, dumę IV pt. Powstanie z Dum podolskich Tymona Zaborowskiego), dwa fragmenty poezji ludowej (z Podola i spod Krakowa), wreszcie dwa wiersze autorstwa samego Jakubowskiego (być może napisana od razu po angielsku Dedykacja i kończący cały tom utwór Song, będący przekładem sonetu Kamieniec).

17 S. Pigoń, Syn Malczewskiego, „Ruch Literacki” 1930, nr 3; J. Krzyżanowski, A.A. Jakubowski. Syn Malczewskiego, w: tegoż, W świecie romantycznym, Kraków 1961; M. Dernałowicz, Antoni Malczewski, Warszawa 1967.

A.A. Jakubowski, Wspomnienia... 
Juliana Maślankę w 1973 roku budzi coraz większe zainteresowanie zarówno badaczy, jak i czytelników, czego konsekwencją są wcale już liczne prace filologów o Jakubowskim, a nawet niepublikowana powieść biograficzna Juliusza Łyskawy pod tytułem August Antoni Jakubowski ${ }^{19}$. Było to życie krótkie, niezwykle dramatyczne i burzliwe, robiące wrażenie nawet na tych współczesnych odbiorcach literatury, którzy niezbyt interesują się romantyzmem ${ }^{20}$.

Chciałbym tu przyjrzeć się kwestii niedrugorzędnej: mianowicie sposobowi, w jaki Jakubowski połączył „obiektywną” narrację o polskiej literaturze, historii, oświacie, zupełnie nieznanych Amerykanom, z ekspresją własnego doświadczenia świata, które naznaczą: samotność, oderwanie od rodziców i rodzinnego Podola, areszt, deportacja, zdobywanie sobie miejsca w Ameryce, przygnębienie, choroba, depresja i desperacja aktu samobójczego. Z jednej strony, Wspomnienia polskiego wygnańca przynoszą ujętą w formę eseju, złożonego $\mathrm{z}$ dziesięciu części ${ }^{21}$, wiedzę o Polsce, jej kulturze, wiedzę dopełnioną tłumaczeniami na angielski utworów Adama Mickiewicza, Antoniego Malczewskiego, Juliana Korsaka, Maurycego Gosławskiego, Tymona Zaborowskiego, poezji ludowej i w końcu własnych tekstów Jakubowskiego. Z drugiej, są przejmującym wyznaniem egzystencjalnym - wyrazem osobliwej, jedynie Jakubowskiemu właściwej odmiany pesymizmu, łączącego melancholię, delectatio morosa i pragnienie zemsty na zaborcach, którzy zniweczyli życie narodu i tak wybitnej jednostki, jak Jakubowski.

\section{ESEJ I EXODUS}

Pisarz ujmuje swe dzieło w kształt fragmentu, niedopełnionych „ułomków”, „szkicu”22. „Zamierzałem napisać historię, a spisałem jedynie jej ułamki” - po-

19 Zob.: J. Maślanka, Poeta tragiczny, „Ruch Literacki” 1972, nr 5; E. Żuk, „The Remembrances of a Polish Exile” Antoniego Augusta Jakubowskiego, „Ruch Literacki” 1979, z. 5; J. Ławski, W romantycznym mroku gwiazd. Wyobraźnia katastroficzna Augusta Antoniego Jakubowskiego, w: tegoż, Bo na tym świecie Śmierć. Studia o czarnym romantyzmie, Gdańsk 2008; tegoż, Głos „polskiego wygnańca” o Ukrainie w Ameryce w 1837 roku po angielsku, „Ucrainistica” 2014, z. 12. Omówienie niepublikowanej, dostępnej w wersji elektronicznej powieść Łyskawy - zob. M. Białobrzeska, Antoni Malczewski. Literackie mitologizacje biografii, Białystok 2016.

Z. Wardziński, English Publications of Polish Exiles in the United States: 1808-1897, „The Polish Review” 1995, nr 4. Zob. także: J. Ławski, Siedem. O Auguście Antonim Jakubowskim, w: Nihilizm i historia. Studia z literatury XIX i XX wieku, pod red. M. Sokołowskiego i J. Ławskiego, Białystok 2009, s. 17-78.

21 Jak się wydaje, była to kompozycja optymalna, przystosowana do wymagań odbiorcy, który niewiele wie o Polsce.

22 „Jednak nie mając księgozbioru, do którego mógłbym sięgnąć, a jedynie swoją własną pamięć, pisząc w języku, który znam w stopniu tylko niewielkim i wspierany tylko przez 
wiada $^{23}$. Akt pisania okazuje się tu więc poniekąd rozczarowaniem, i - co ważniejsze - ekspresją mroków historii oraz duszy w swobodnej, sylwicznej, eseistycznej formie.

Znaczenie fundamentalne ma tutaj metatekst tytułowy: Wspomnienia polskiego wygnańca. Jakubowski nie eksponuje swego autorstwa, podpisując się pod Dedykacja inicjałami A.J. To jakby semi-autorstwo, półotwartość. Autor jest do rozpoznania, lecz wyraźnie jego los uniwersalizuje się w figurze „wygnańca”. Exodus, gwałt wygnania - to podstawowy wymiar egzystencji, ujawniany przez tekst. Poznajemy wizje Polski i jej kultury, ukazane z punktu widzenia skandalu historycznego i egzystencjalnego, jakim jest wygnanie: brutalne wykorzenienie z ojczyzny, o czym niemal krzyczy cały utwór. Wspominanie staje się tu konstruktywnym aktem ustanawiania egzystencji - przesuwa ją z teraźniejszości, odsuwa od planów przyszłości, ustanawiając podmiot wspominający szczęścia i katastrofy życia tak wspólnoty, jak i jednostki. Ostatecznie to melancholia, wanitatywne nastawienie podmiotu i furia złości są tu egzystencjalno-estetycznym filtrem, przez który będą odsłaniane Amerykanom losy Polski, położonej gdzieś daleko w Europie.

Przestrzenną i czasową, ledwie maskowaną dominantą okażą się tu dzieje ziem ukraińskich, utraconych przez wspominającego pisarza. Nie ma więc mowy o konstruowaniu dzieła historiograficznego, pisaniu „historii”; Jakubowski tworzy esej, który może nawet chętniej nazwałbym romantyczną sylwą. Scalającą perspektywę wyznacza tu desperacja wspominania, które jest jedynie możliwym aktem scalenia i zarazem staje się ono niemożliwe. Życie jako niekończący się akt wspominania obumiera, co w końcu wyznacza prędzej czy później kres narracji, fabuły i samego narratora-wspominacza.

Oto „polski” los wygnańczy, zapisany jako wydobyte z głębi tej kuli śnieżnej, do której podmiot i jego pamięć porównywał Henri Bergson ${ }^{24}$, pokłady wspomnień-strat tego, co bezpowrotne, ostatecznie nieobecne. Czy jest tu jakiś horyzont przyszłości, perspektywa wydobycia się z tej depresji młodości, która nie chce dorastać, bo wyrzucono ją z ojczystego i rodzinnego podglebia?

Zdaje się, iż taki horyzont może wyznaczać Dedykacja skierowana Do Amerykańskich Dam (To the Ladies of America). To dziesięciowersowy wiersz, próbujący nawiązać relację między autorem a całym kręgiem nowych odbior-

kilka osób, dzięki którym słowa te ukazują się drukiem, uznałem, że niemożliwością byłoby opisać te sprawy w pełni. Oprócz szkiców o poezji i oświacie załączyłem kilka innych fragmentów w formie apendyksu i powiastki" (A.A. Jakubowski, Przedmowa, w: tegoż, Wspomnienia..., s. 65) .

23 Tamże.

24 Zob. H. Bergson, Pamięć i życie, wyb. G. Deleuze, przeł. A. Szczepańska, Warszawa 1988. 
czyń: Amerykanek. Lecz jest to tekst pozornie dialogiczny, zamykający doświadczenie autora w opozycjach: północ - południe, zima - lato, więdnięcie - rozkwit, ciemność - słoneczna jasność, ojczyzna - wygnańcze schronienie, rozpacz - pociecha, znużenie - śpiew poety, upadek - lot (wzlatywanie), rozpacz - zachwyt. O ile osiem początkowych wersów kreuje jeszcze szansę zadomowienia „ptaka wędrownego” w krajach „południa”, o tyle wersy końcowe przekreślają te nadzieje: „Pieśni wygnaniec im sam śpiewa rzewnie, / Chociaż niewiele one znaczą pewnie" ${ }^{25}$. I ów podpis: J.A. Nie widzę tu autorskiej kokieterii - raczej rezygnację i szczerą niepewność, czy w ogóle warto mówić, pisać...

Ileż kontekstów wygnańczych - od żalów Owidiusza spisywanych w Tomis nad Morzem Czarnym po poezję wygnańców polistopadowych - można by tu zarysować ${ }^{26}$. Chociaż podkreślę, że doświadczenie Jakubowskiego jest jedyne w swoim rodzaju: oto prawie dziecię, nastolatek, zostaje aresztowany, miesiącami więziony, wywieziony z kraju dzieciństwa. Odmawia mu gościny tak napuszona ideami rewolucyjnymi i napoleońskimi Francja. Zamiast powrotu do Austrii, do więzienia, musi wybrać z dwustu trzydziestoma pięcioma ziomkami deportację do Stanów Zjednoczonych. Jest wygnany dosłownie. Nie uciekł za granicę, został z ojczyzny brutalnie wypędzony - do odległego o tysiące mil „Nowego”, ale obcego „Świata”.

Uwagi wstępne (Introductory Remarks) pastora prezbiteriańskiego Sprague’a zdają się zarysowywać ciepły, przyjazny horyzont akceptacji, swoistego usynowienia wygnańców, w tym „młodego dżentelmena” (a young gentleman) przez społeczność Albany i Ameryki. Więcej - pastor wyraża szczere zadziwienie geniuszem dziewiętnastolatka:

Zaświadczam, iż gdy czytałem te strony, głównym uczuciem, jakiego doświadczałem, było zdumienie, że dziewiętnastoletni młodzieniec, który dziewięć miesięcy temu ledwo był w stanie powiedzieć słowo po angielsku i prócz swej własnej pamięci i myśli nie miał żadnych źródeł, mógł stworzyć owe okazy angielskiej poezji i polskiej historii w tym tomie zawarte. Nie mam też najmniejszych wątpliwości, że wszyscy, którzy to przeczytają, zgodzą się ze mną, iż znamionują one geniusza, który rozwinięty mógłby opromieniać swą chwałą każdy kraj. ${ }^{27}$

Wszystko więc zdaje się otwierać perspektywę kreatywnego i dostatniego życia przed Jakubowskim: nauczycielem, obywatelem, polskim Amerykani-

25 A.A. Jakubowski, Dedykacja, w; tegoż, Wspomnienia..., s. 62.

26 Zob. T. Tomasik, „Inny” jako kategoria dyskursu autobiograficznego (od Marka Aureliusza do Montaigne'a); S. Rzepczyński, Autobiografia jako hagiografia. Uwagi o paradoksalności „Autobiografii artystycznej” Norwida, w: Autobiografizm i okolice. Prace ofiarowane Profesor Małgorzacie Czermińskiej, pod red. T. Sucharskiego i B. Żynis, Słupsk 2011.

27 W.B. Sprague, Uwagi wstępne, w: A.A. Jakubowski, Wspomnienia..., s. 64. 
nem. I pastor Sprague daje jednak znać, iż przyjazna inkorporacja wygnańców do społeczeństwa amerykańskiego zderza się w przypadku Jakubowskiego z jego wyborem: „Autor owej pracy ma właśnie opuścić nasze miasto, chcąc spotkać się z mieszkającym w Meksyku, jak ustalił niedawno, bliskim krewnym" ${ }^{28}$. Kończy tekst pastora szczere błogosławieństwo i życzenie:

Niech go ochrania i niech błogosławi Opatrzność, a choć jego przeznaczeniem jest teraz śpiewać w obcym kraju pieśn wygnańca, oby dożył on dnia, w którym swym geniuszem opisywać będzie oswobodzenie swojej ojczyzny.

Albany, 30 stycznie 1835 roku $^{29}$

W.B. Sprague

To jednak zdanie rozpatrywałbym jako wyraz dystansu duchowego wobec upartej, szalonej i dzikiej decyzji podróży do Meksyku, rodzaj ostrzeżenia pełnego niepokoju. Także Marcin Rosienkiewicz, przyjaciel poety, pisał o podróży Jakubowskiego do Meksyku bez entuzjazmu ${ }^{30}$. Książka Jakubowskiego okazuje się pożegnaniem, otwarciem kolejnego etapu wędrówki-wygnania. I perspektywę dialogu $\mathrm{z}$ amerykańskim czytelnikiem czyni to dyskusyjną: napisał The Remembrances i... odjeżdża? Ucieka? Gna dokąd i po co? Do krewnego? Zastępcza rodzina, społeczność Albany, mogła się czuć rozgoryczona i zaniepokojona odjazdem młodziana.

Migotanie konwe ncji (tytułu, dedykacji, wstępu) i egzys te n c ji (wygnanie, samotność, podróż w nieznane) jest tu wszechobecne. Ile to „wspomnień" w Polsce i o Polsce napisano - ale tylko to jedno w Ameryce po angielsku. Ile figur „wygnańca” wyeksploatowano po 1795 roku. A ile razy poprzedzano teksty Polaków cudzoziemskimi wstępami. Jednak tylko Jakubowski zdawał się przekuwać konwencję w pionierskie dokonanie: zarysować historię odległej ojczyzny znanych Amerykanom herosów wolności, Tadeusza Kościuszki i Kazimierza Pułaskiego, tłumaczyć wiersze polskich romantyków niemal „na żywo” (zna już III część Dziadów z 1832 roku), nawiązywać intelektualny i duchowy kontakt ze wspierającym go środowiskiem prezbiterian. „Zdaje się", że tak właśnie było lub miało być. Bo nie było do końca.

28 Tamże.

29 Tamże.

30 „Mimo najszczerszych przekładań i odradzań przyjaciół, uskutecznił swe postanowienie, lecz nie mogąc znieść południowego klimatu i nie doznawszy od swego krewnego przyjęcia, jakiego się spodziewał, wrócił do Nowego Jorku z znacznie nadwerężonym zdrowiem. Przebywszy w tym mieście długą i ciężką chorobę, został zdefigurowany garbem na plecach, co najmniejszego na nim nie zrobiło wrażenia; sam nawet, żartując ze swojej figury, nazywał się Ezopem” (M. Rosienkiewicz, dz. cyt., s. 69). 
Przedmowa (Preface) Jakubowskiego ujawnia głęboką, trawiącą autora melancholię „mrocznego" momentu życia, gdy przychodzi człowiekowi je, owo życie, wspominać „w poszukiwaniu duchowej strawy”. Jest to czas podsumowań:

Jest taki czas w naszym życiu, kiedy wszystkie myśli biegną w przeszłość w poszukiwaniu duchowej strawy. Mroczny to moment, zdarza się to bowiem tylko wtedy, gdy przestajemy zachwycać się wspaniałością chwili obecnej lub nadziejami na przyszłość. Czas ten zbyt szybko nastąpił w życiu wygnańców. Dla wędrujących i samotnych jedynym skarbem są wspomnienia. Jako iż sądzę, że mogą one być dla niektórych ciekawe, postanowiłem podzielić się nimi z czytelnikami. Jednak gdym tylko począł wydobywać mą pamięć $\mathrm{z}$ popiołów, tyle się nagle pojawiło przede mną zjaw, że na powrót pogrzebałem je w swej piersi. Zamierzałem napisać historię, a spisałem jedynie jej ułamki. ${ }^{31}$

Jakkolwiek czytać wyznanie autotematyczne Jakubowskiego, zawsze odsłania ono pustkę, samotność, zagubienie i niepogodzenie ze stratą. Właśnie tu widać, co znaczy formuła tytułu: wspominamy wtedy, „gdy przestajemy zachwycać się wspaniałością chwili obecnej lub nadziejami na przyszłość”. Ta autodiagnoza otwiera mortualne imaginarium pamięci: „wydobywać pamięć z popiołów”, „zjawy”, pogrzebać „w swej piersi” ${ }^{22}$. Wskrzeszanie i grzebanie straty (domu, ojczyzny, miłości) sprawia, iż pisarz może dać tylko fragment, eseistyczny ciąg szkiców. Jakubowski wyznaje, że pisze opierając się na zasobach pamięci - tylko własnej pamięci spraw polskich. Przywołuje topos skromności, akcentuje słabą znajomość angielszczyzny. Można by go nawet nazwać wygnańcem-niewdzięcznikiem: oto wspiera go „tylko [...] kilka osób”. Ostatnie zdanie aktywizuje znaną z dedykacji symbolikę florystyczną (tam: „kwiecia woń południowego”), ale robi to w minorowej tonacji (tu: „owe kwiaty polskie ubogie są i brak im koloru”) żebrzącego o „wspomnienie” wygnańca, który liczy na empatię amerykańskich dam.

Widać, jak wszystko w tej książeczce jest misternie powiązane: konwencja (zwrot do..., dedykacja, tytuł) ma otworzyć drogę do czytelnika, lecz też skryć rozpacz „mrocznego momentu” (a dark moment), który za wcześnie przyszedł do dziewiętnastolatka. Wspominać życie w dziewiętnastej wiośnie tegoż życia - to mogą lub muszą czynić tylko śmiertelnie chorzy. Wspomnienia polskiego wygnańca są takim „snem całego życia”, o jakim pisze w Godzinie myśli (1834) niemal równocześnie Słowacki:

A.A. Jakubowski, Przedmowa, w: tegoż, Wspomnienia..., s. 65.

32 Wybrzmiewa tu przerażający motyw tanatyczny: oto grzebanie myśli we własnym wnętrzu, zdradzające absolutną pustkę wokół, samotność. A zarazem - chyba - słychać echo motta z Jean Paula do IV części Dziadów. Zob. A. Kowalczykowa, Kim jest Gustaw?, w: tejże, Wokół romantyzmu..., s. 13-20. 
Gdy lampa gaśnie, kiedy pieśń piastunek ścicha, Kiedy się małe dziecko $\mathrm{z}$ kołyski uśmiecha,

Ma sen całego życia... A gdy tak przemarzą,

Dzieci na świat nieznany smutną patrzą twarzą

I bladym przerażają czołem od powicia;

Smutne pomiędzy ludźmi - bo miały sen życia. ${ }^{33}$

Aczkolwiek u Słowackiego przeszłość oświetla słońce, sen życia jest też snem przyszłości, która zwycięża śmierć. U Jakubowskiego jest to - oweż wspomnienia - wyblakły i bezwonny surogat szczęśliwości, lot nad życiem, który poprzedza śmierć. To daje się tutaj odczuć.

Przyszłość okazuje się niemożliwością, strata absolutem, a teraźniejszość momentem zawieszenia między wspomnieniem a śmiercią.

Szkic o poezji polskiej (Essay on Polish Poetry) i Historyczny szkic o oświacie $w$ Polsce (Historical sketch of education in Poland) to informacyjne części eseju, rzucające światło na los wygnańca-poety, ale pisane bez intencji wyjawienia czegoś z głębi życia wewnętrznego. To dopiero Polscy kochankowie (The Polish Lovers), powiastka wzniosła, w stylu libretta operowego, dopowiadają: że Jakubowski utracił świat matki (daje motto z wiersza Mickiewicza Do Matki Polki), że miłość w świecie horrendalnej historii jest tylko utopią heroizmu rozstania (rozstanie Haliny i Kazimierza), że w końcu, jak sugeruje już motto, wszystko i tak skończy się szubienicą - dosłownie bądź metaforycznie (Moskale wieszają Kazimierza); że jest tylko „smutna”, „straszna” „ofiara życia i krwi” owego „bohatera”, pociągająca za sobą śmierć Haliny ${ }^{34}$. Finał - z ducha osjaniczny - Polskich kochanków zdaje się parafrazą obrazową finału Marii Malczewskiego. Halina umiera na grobie Kazimierza momentalnie, florystycznie zamknięta w symbolu „widoku róży”:

A jednak znad grobu wzniosły się modlitwy, choć nie zmówili ich księża, na jego prochy padały łzy, choć wojownicy ich nie ronią. Postać piękna klęczała tam, postać jego ukochanej, jej duch piękny tam płakał, duch jego miłej. Blady księżyc wzeszedł i zaszedł, a ona wciąż klęczała przy mogile.

Rankiem przyszło chłopstwo spojrzeć na grób partyzanta, a ona wciąż klęczała, zimna jednak i blada. Piękny kwiat Podola zwiądł i umarł, niczym widmo róży na mo-

33 J. Słowacki, Godzina myśli, w: tegoż, Powieści poetyckie, oprac. M. Ursel, Wrocław 1986, s. 271. Zob. w tym kontekście: L. Zwierzyński, „Ja” poetyckie Słowackiego - próba ujęcia konstelacyjnego, w: Zanikanie i istnienie niepetne. W labiryntach romantycznej i wspótczesnej podmiotowości, pod red. A. Dąbskiej-Kossakowskiej, P. Paszka, L. Zwierzyńskiego, Katowice 2013.

34 Jak wskazują imiona, niemało tu konwencji po prostu sentymentalnej, późnooświeceniowej. O literackich Halinach zob. Z kręgu Marii Wirtemberskiej. Antologia, t. 1-2, oprac. i wstęp A. Aleksandrowicz, Warszawa 1978. 
gile wojownika, jej duch jednak, wolny i lekki, połączył się już z duszą Kazimierza. Taki był los polskich kochanków. ${ }^{35}$

Przecież podobnie ojciec umiera na grobie córki w Marii, klęcząc, modląc się:

Raz, i północ minęła, a Miecznik nie wraca;

I gdy patrząca Czujność nadzieję utraca -

Gdy dziko grają trąby - a ze snu, jak z procy,

Rzucili się rycerze k’zemście lub pomocy -

Znaleźli go w cmentarzu; przy córki i żony

Przyległych dwóch mogiłach klęczał nachylony:

Taż sama w ustach słodycz, a w czole sędziwość -

Taż sama bladość twarzy, ale oczu żywość -

Czapka, wąsy, dla Polski straszydło na wrogi -

I żupan ten sam czarny - tylko że gdy trwogi

Odgłos z trąby wojennej dochodził daleki,

Nie porwał się do korda - już spał - spał na wieki.

I cicho - gdzie trzy mogił w posępnej drużynie;

I pusto - smutno - tęskno w bujnej Ukrainie. ${ }^{36}$

Jakubowski daje happy end zaświatowy niczym Mickiewicz w IV części Dziadów: „[...] jej duch jednak, wolny i lekki, połączył się z duszą Kazimierza"37. Malczewski otwiera otchłań pustki i nieskończonego smutku, żałoby, opłakiwania. U Malczewskiego pojawią się jednak modlitwa i cerkiew jako znaki konsolacji - może niepewnej, ale na pewno rozważanej. Tymczasem Jakubowski - wbrew optymizmowi połączenia duchów po śmierci - nie daje żadnej pociechy. Łączą się dusze, ale - co to znaczy? Co znaczy, skoro religia jest tu kontestowana, a dominantą jest czysta negatywność: „nie”...

Jeden głos głośny podniósł się z tłumu, długi i przeszywający żałosny płacz, płacz kobiety, domyślić się można, z której wydobył się piersi.

Wieczorem tego samego dnia ciało wojownika pogrzebano pod szubienicą. Kapłani Boga nie zmówili modlitw za jego dusze, sztandary czarne nie załopotały nad jego ciałem, nie było muzyki żałobnej, werbli głuchych, bicia w dzwony i lamentów, które odprowadziłyby go na wieczny spoczynek. ${ }^{38}$

Syn nawiązał do ojca - jednak! Oto w Marii znajdujemy pogodną i ironiczną wiwisekcję ciekawskiej natury ludzkiej:

A.A. Jakubowski, Polscy kochankowie, w: tegoż, A.A. Jakubowski, Wspomnienia..., s. 94. I tutaj znać wpływ konwencji: sentymentalnej i osjanicznej.

36 A. Malczewski, Maria. Powieść ukraińska, s. 182 (Pieśń II, ustęp XX).

37 A.A. Jakubowski, Polscy kochankowie, s. 94.

38 Tamże. 
Na ukraińskiej cerkwi błyszczą się trzy wieże;

A ukraińskie baby szepczą swe pacierze:

Biją we dzwony żaki, i zysk sobie krzeszą;

Ludzie dobrzy - czy pogrzeb, czy to chrzciny - śpieszą. ${ }^{39}$

U Jakubowskiego dramat kończy się podobnie: „Rankiem przyszło chłopstwo chcąc spojrzeć na grób partyzanta, a ona wciąż klęczała, zimna jednak i blada” ${ }^{40}$. Oto ironia, sarkazm, kpina: „ludzie prości” i „chłopstwo” zaspokajają nikczemność, przyglądając się klęsce życia. Ironia to gorzka, bez pocieszenia i bez przezwyciężenia. U autora Marii dalekie niebo jest - u Jakubowskiego... Bóg raczy wiedzieć! Zostaje pustka, nieobecność, niebycie: „Taki był los polskich kochanków”" ${ }^{41}$

Tyle na poziomie melancholii zdaje się mówić wygnańcza książeczka. Epicka wzniosłość odsłania los wygnańców: wyrok śmierci.

FURIOSO, AMOK, POMSTA...

Doświadczenie Jakubowskiego nie jest jednakowoż tylko zanurzeniem się $\mathrm{w}$ rozpaczy i samotności. Jest biograficznym wstrząsem, przynoszącym - w warstwie wewnętrznej - furię niezgody, prawdziwej żądzy zemsty. Zaświadcza to jego poezja. W wierszu Aut Brutus, aut nihil złorzeczy on:

Kto wroga krew pije,

Choćby to krew brata, syna,

Z mężnym sercem Rzymianina

Polski Brutus niechaj żyje! ${ }^{42}$

We Wspomnieniach polskiego wygnańca wątek egzystencjalny, tak wyrazisty na ich początku, wyrasta $\mathrm{z}$ wątku politycznego - zbrodni deportacji polskich patriotów. Przyczyny deportacji Polaków to pisany żywo miniesej, charakteryzujący dwa odłamy emigracji polskiej: francuski i galicyjski. Galicja jest tu ziemią przyjazną Polakom tylko do czasu: zaniepokojony ruchami patriotycznymi, takimi jak partyzantka Zaliwskiego ${ }^{43}$, rząd Austrii posta-

39 A. Malczewski, Maria. Powieść ukraińska, s. 181 (Pieśń II, ustęp XX). Zob. też M. Białobrzeska, Mit Antoniego Malczewskiego w poezji polskiej, w: Pogranicza, Kresy, Wschód a idee Europy, Seria 2: Wiktor Choriew in memoriam, idea i wstęp J. Ławski, red. A. Janicka, G. Kowalski, Ł. Zabielski, Białystok 2013.

40 A.A. Jakubowski, Polscy kochankowie, s. 94.

41 Tamże.

42 A.A. Jakubowski, Aut Brutus, aut nihil, w: tegoż, Poezje, s. 8.

43 Jakubowski nawiązuje bezpośrednio do partyzantki Zaliwskiego w Przyczynach emigracji Polaków: „W 1833 roku emigranci we Francji zaplanowali wojnę partyzancką” (A.A. Jakubowski, Przyczyny..., s. 96). 
nawia deportować wszystkich popowstaniowych uchodźców z imperium carów.

Wynikałoby z tego, że: po pierwsze, Jakubowski jako nastolatek brał udział w powstaniu listopadowym w Królestwie Polskim, gdzie rządziła Rosja; po drugie, iż uciekł do Austrii, do Galicji, na swe rodzinne Podole; po trzecie, że liczył, jak wszyscy inni, na możliwość osiedlenia się we Francji, którą charakteryzuje wcześniej jako kraj rewolucji, liberalizmu, udzielający schronienia Polakom od czasów Kościuszki. Kraj, któremu wiernie służyli Polacy za Napoleona:

Ludzie ci, żywiący nadzieję na [odrodzenie] kraju, szli wszędzie za wielkim Napoleonem. Ich kości bieleją na równinach Włoch, Niemiec, Hiszpanii i Santo Domingo.

Jednak Napoleon miast przywrócenia [bytu państwowego] Polski, dał wolność tylko małej części kraju nazwanej Księstwem Warszawskim. ${ }^{44}$

Napoleon zawiódł ${ }^{45}$. Nadzieje braterstwa z Francją odżyły dzięki Lafayette'owi:

W czasie naszej rewolucji, patriarcha wolności, czcigodny Lafayette, starał się zwrócić ku nam uczucia narodu francuskiego, a po klęsce, wciąż żywiliśmy nadzieję na sukces, widząc [rosnące] w Europie tendencje do republikańskich form rządów i poglądów liberalnych. Nasi rodacy z Galicji, która wpierw była im schronieniem, przybyli do Francji, woląc wygnanie od amnestii despoty. ${ }^{46}$

I znów zawód: Francja nie okazała pomocy, darmo szukano „współczucia i pomocy u Francuzów" ${ }^{47}$. Jakubowski daje namiętny, pełen urazy wywód pokazujący tę drugą twarz Francji: obłudną. Kiedy spodziewał się wraz z innymi azylu - znalazł odmowę, skazano go na wygnanie do Ameryki, bo przecież nie sposób było wracać do Rosji:

Byliśmy zdeterminowani raczej przekroczyć ocean, niż wracać do kraju, który przestał być nasz. Postanowiliśmy jechać. Austriacy kazali nam spisać nasz postanowienie, aby później pokazać Europie, iż nasza decyzja była dobrowolna, ale prawie wszyscy napisali, że „naszą wolą jest udać się do Francji, jednak, jako że powiedziano nam, iż nie zostaniemy tam przyjęci, zmuszeni przez austriacki rząd musimy jechać do Ameryki”. Potem podążyliśmy do Triestu, gdzie wsiedliśmy na statek. Całą resztę naszej historii znacie. $^{48}$

44 Tamże, s. 95.

45 Sprawę tę analizuję w pracy: J. Ławski „To zawsze wielki człowiek kto największy z ludzi"? (Napoleon, Malczewski, Jakubowski), w: Literatura, pamięć, kultura. Prace ofiarowane Profesor Elżbiecie Feliksiak, pod red. E. Sidoruk i M.M. Lesia, Białystok 2010.

46 A.A. Jakubowski, Przyczyny..., s. 95.

47 Tamże.

48 Tamże, s. 97. 
Drżenie serc, bolesna walka, rozdarcie, a nade wszystko zaskoczenie zakłamaniem Francji, z którą długo po 1837 roku Polacy, jak choćby Mickiewicz, będą wiązać - często wyśmiewane przez Francuzów - nadzieje polityczne i duchowe na odrodzenie Europy. Autor Buntów Chmielnickiego i Ode to Napoleon zamyka swój błyskotliwy, emocjonalny opis cytatem z Ksiag pielgrzymstwa polskiego (1832) Mickiewicza. Samotność wygnańców zostaje zamknięta $\mathrm{w}$ figurze pielgrzyma. Cytat Mickiewiczowski nie do końca zgadza się z tonacją wygnańczą Wspomnień polskiego wygnańca: „Duszą narodu polskiego jest polskie pielgrzymowanie” („The soul of the Polish nation is the Polish pilgrimage [...]” ${ }^{49}$ ). W oryginale Mickiewicza: „Duszą narodu polskiego jest pielgrzymstwo polskie" ${ }^{\circ 0}$. Co więcej, cytat z Ksiąg pielgrzymstwa polskiego wprowadza postać Chrystusa, Mesjasza, który usensownia tym samym doświadczenie wygnania jako wybór bycia apostołem Boskiej prawdy: „Powiedział Chrystus: «ci, którzy chcą iść za mną, muszą zostawić ojca i matkę i ryzykować dla mnie swoje życie»” ${ }^{1}$. W oryginale: „Powiedział Chrystus: «Kto idzie za mną, niech opuści i ojca swego, i matkę swoję, i odważy duszę swoję»" ${ }^{52}$. Mickiewicz na planie analogii zrównuje idee Ojczyzny i matki/ ojca, misji Chrystusa - oraz misję Wolności, apostolstwa - i pielgrzymstwa. Jak wiemy, była to zbawienna dla wielu emigrantów strategia przekształcająca katastrofę w usensownioną przez wolę Opatrzności misję Boską.

Nie jest to jednak droga Jakubowskiego. Jego towarzyszy, „złamanych nieszczęściem”, owszem, ale nie jego. Dlaczego? Wyjaśnia to Odezwa Komitetu Polskiego w Paryżu do polskich emigrantów (Address of the Polish Committee in Paris, to the Polish Emigrants), przywołana in extenso we Wspomnieniach polskiego wygnańca, podpisana po klęsce powstania listopadowego - 25 grudnia 1831 roku - przez takie osobistości jak: Joachim Lelewel, Walenty Zwierkowski, Leonard Chodźko, Roman Sołtyk, Tadeusz Krępowiecki, Antoni Przeciszewski, Karol Kraitsir, Antoni Hłuszniewicz, Adam Gurowski i Walerian Pietkiewicz. To mocna, zdecydowana, wprost okrutna odpowiedź emigrantów okupantom. Odpowiedź mścicieli, jakże daleka od tonu Ksiag pielgrzymstwa polskiego. W końcowej jej części pobrzmiewa nawet quasi-nihilistyczna desperacja:

Groby waszych pomordowanych braci otworzą się, a mściciele powstaną ze szkieletów. Wywołajmy ich duchy, jednak z mieczem w dłoni, inaczej bowiem nie poznają nas,

Tamże.

A. Mickiewicz, Księgi pielgrzymstwa polskiego, w: tegoż, Dzieła..., t. 5: Proza artystyczna i pisma krytyczne, oprac. Z. Dokurno, teksty franc. przeł. A. Górski, Warszawa 1999, s. 21.

A.A. Jakubowski, Przyczyny..., s. 98.

A. Mickiewicz, Księgi pielgrzymstwa polskiego, s. 30. 
a jeśli hańbę naszą zauważą, ich lęki powiedzą niebiosom, iż naszym tchórzostwem zakłóciliśmy ich ostatni odpoczynek.

Niech niezależna i wolna Polska Jagiellonów albo wieczna śmierć będą nam na ustach! $!^{53}$

Jakubowski wybrał te znaczenia, jakie niesie Odezwa..., a nie opcję, jaką proponują Księgi pielgrzymstwa polskiego Mickiewicza. Zda się, iż rozumiał wybory emigrantów-mesjanistów, pojmował strategię przystosowania się do życia w Ameryce, którą obrał na przykład Karol Kraitsir (emigrant ${ }^{54}$ ). Ale ani w poezjach, ani we Wspomnieniach polskiego wygnańca nie dał śladu akceptacji dla idei mesjanizmu lub drogi asymilacji lub wrastania w społeczność emigracyjną Ameryki. Ani rola wygnańca, ani imigranta, emigranta, ucikiniera - nie były jego. W Dodatku zawierajacym krótka wzmiankę o Ukrainie i Podolu (Appendix, containing a short notice of Ukraine and Podolia) nawiązuje Jakubowski liryczny dialog z przestrzenią straconą, rodzinną, krajem lat dziecinnych: „O Podolu będę jeszcze mówić. Była to kolebka mego dzieciństwa, miejsce, gdzie zakwitły pierwsze kwiaty mych młodzieńczych myśli”" Metaforyka florystyczna mówi tu wszystko: po rozkwitaniu przyszło więdnięcie. Potem nastąpi zwiędnięcie. Duma Zaborowskiego, zacytowana i przełożona przez Jakubowskiego, aktywizuje irredentystyczno-mścicielskie akcenty:

$$
\begin{aligned}
& \text { Nieszczęścia dzieci, karmione rozpaczą, } \\
& \text { Chwytajcie łzami zatrute pałasze! } \\
& \text { Rzucajcie domy - które już nie wasze - } \\
& \text { Rzucajcie matki, co nad wami płaczą! } \\
& \text { Owocem waszych będzie łez i trudów. }{ }^{56}
\end{aligned}
$$

Lecz, jak widzimy, ostatni akord Wspomnień polskiego wygnańca uderza melancholią - tonacją muzyki nocy i ruin, wybrzmiewającej z obrazu zniszczonych „bastionów Kamieńca”: „Gdzie sztandar wolności powiewał, / Żałobne chorągwie łopoczą" ${ }^{57}$. Pragnienie zemsty, wampiryczna chęć odpłaty krwią za krew, złorzeczenia na równi z wizją wolnej ojczyzny - pozostają pragnieniem, chwilowym, dość mrocznym, wychyleniem podmiotu w przy-

53 A.A. Jakubowski, Przyczyny..., s. 100.

54 Kraitsir należał do paryskich emigrantów polskich podpisanych pod odezwą Komitet narodowy Polski w Paryżu do wojowników polskich! (25 XII 1831), a potem był liderem emigracji polskiej w Ameryce (zob. J. Lerski, A Polish Chapter in Jacksonian America. The United States and the Polish Exiles of 1831, Madison 1958).

55 A.A. Jakubowski, Dodatek zawierający krótką wzmiankę o Ukrainie i Podolu, w: tegoż, Wspomnienia..., s. 104.

56 Tegoż, Insurekcja [Insurection], w: jw., s. 105.

57 Tegoż, Pieśń [Song], w: jw., s. 106. 
szłość. Ale i przyszłość, i teraźniejszość osuwają się w rozpadlisko przeszłości, skąd wygnaniec dobywa wspomnienia. Wspominając - zamiera.

\section{ESTETYCZNA OSOBLIWOŚĆ}

Czarny romantyzm Jakubowskiego daleki jest od jakiegokolwiek idealizmu. Łączy egzystencjalną głębię z politycznym losem, kondycję wygnańca z przeznaczeniami rozmarzonego poety. Poeta ów jest melancholikiem-mścicielem. Niesie, o czym pięknie pisał Rosienkiewicz, pomoc współbraciom, lecz sam pozostaje samotny i - w końcu - skazany na zatratę. Dopełni fatalności jego życia nieuleczalna choroba. Historię wesprze bezwzględna natura. Wobec takich okoliczności pomoc wspólnoty okaże się daremna. Jakubowski postanowi, że nie chce żyć. W tym przypadku dzieło i los są jednym. Wszelkie pozy i stylizacje, gry komunikacyjne i tak stają się prawdą zaprzeczoną: przez śmierć.

Spojrzenie z innej strony - tradycji literackiej - ujawnia rozdarcie Jakubowskiego między wzorcem romantyzmu prezentowanym przez młodego Mickiewicza (IV część Dziadów) a inspiracją romantyzmu czarnego spod znaku reprezentantów szkoły ukraińskiej (Malczewski, Goszczyński, w mniejszym stopniu Zaleski). Jakubowski prezentuje jednak własną, oryginalną drogę wyboru estetycznego: jest mrocznym egzystencjalistą, a zarazem formalistą, „parnasistą" jako liryk.

Jako eseista anglojęzyczny, przynależąc do dwu kultur, amerykańskiej i polskiej, idzie drogą pewnego umiaru. Nasącza esej treściami egzystencjalnymi, ale konstruuje logiczną, nader złożoną, bo składającą się z dziesięciu części całość: od tytułu i dedykacji do Dodatku. Uzupełnijmy, że Wspomnienia polskiego wygnańca oświetlają poezję Jakubowskiego, lecz i poezja ta pozwala jaśniej eksplikować niedemówienia eseju. Jakubowski jest mistrzem - zapewne przypadkowo - w balansowaniu między formalną całością a otwartością: wiersze jego nie są ani cyklem, ani spójnym zbiorem. Ich układ zawdzięczamy wydawcy ${ }^{58}$.

58 „Biorąc te okoliczności pod uwagę, edytor starał się nadać obecnej publikacji bardziej przemyślany układ. Nie zachowano zatem przypadkowej kolejności utworów, jaka jest w rękopisie, starając się ułożyć je w miarę możności w porządku chronologicznym. Oczywiście nie rozbito cyklu jedenastu sonetów, ani też nie zmieniono ich układu, choć pisane były w różnych okresach. Jeśli chodzi o układ graficzny poszczególnych utworów, starano się zachować układ rękopisu, jednak w paru wypadkach ewidentnej niekonsekwencji odstąpiono od zasady, np. w wierszu Do... - w rękopisie wyraźnie oddzielone są cztery pierwsze wersy, następne cztery kończą się równo ze stroną, ciąg dalszy zapisany bez podziału na strofy. Dla jasności dodano numerację rzymską do czterech utworów, opatrzonych tym samym tytułem: Dumania" (J. Maślanka, Nota wydawcy, w: A.A. Jakubowski, Poezje, s. 71). 
Z drugiej strony: Wspomnienia polskiego wygnańca to przemyślana całość o meandrycznej, różnogatunkowej strukturze wewnętrznej: szkicu, dedykacji, odezwy, dodatkowo ilustrowana przekładami poezji polskiej na język angielski. Poeta daje tu subiektywno-obiektywną, zbalansowaną wersję czarnoromantycznej wizji świata, która ostateczny wyraz znajduje w formie wspomnień-sylwy-eseju. Za pierwszorzędną, nadrzędną strukturę gatunkową trzeba by tu uznać esej o cechach sylwy i wspomnień, integrujący w sobie takie elementy, jak szkic, odezwa, translacja. Jest to oryginalna, e s i s tyc zna formuła estetyki czarnoromantycznej, chyba jednak nieodosobniona, gdy wziąć pod uwagę pisarstwo Tadeusza Grabowskiego, Zenona Fisza, Józefa Ignacego Kraszewskiego czy Dominika Magnuszewskiego ${ }^{59}$.

Osobliwością Jakubowskiego jest za to - wyniesione ze szkoły krzemienieckiej - jego zakorzenienie myśli i estetyki w oświeceniu i klasycyzmie. Być może jako poeta w Krzemieńcu opanował on podstawy takich gatunków, jak sonet, triolet, dumanie. W kontekście europejskim Jakubowski przywołuje we Wspomnieniach polskiego wygnańca Voltaire’a, Racine’a, braci Śniadeckich, Horacego, Homera, Demostenesa, ale też Shakespeare'a i Petrarkę. Byłby to więc kanon literackiego wykształcenia w guście szkoły klasycystycznej. Wpłynęły zapewne na Jakubowskiego kazania Sprague’a - trudno jednak rozstrzygnąć, jak wpłynęły. Być może ukształtowały ów melancholijno-wspomnieniowo-wygnańczy ton książki, jakże podobny do retorycznych figur mów-kazań pastora, wygłaszanych w 1834 roku w Albany na rzecz polskich przybyszów, imigrantów ${ }^{60}$.

Rzadki to w tym czasie przypadek wpływu środowiska protestanckiego i prezbiteriańskiego na literaturę polską (ale nie jedyny, by wspomnieć innych protestantów: Krystyna Lacha Szyrmę, Wojciecha Kętrzyńskiego, Gustawa Gizewiusza i Celestyna Mrongowiusza) ${ }^{61}$. Dziwi nieobecność wśród przywołanych nazwisk Byrona, Scotta, Hugo i innych luminarzy romantyzmu, którzy w latach trzydziestych stają się poniekąd klasykami nurtu, wydawanymi w dużych nakładach. Byrona wielbił Malczewski, cenił i przekładał Mickiewicz.

59 Por. M. Kwapiszewski, Późny romantyzm i Ukraina. Z dziejów motywu i życia literackiego, Warszawa 2006.

6o Sprague opublikował także te prace, utrzymane w niezwykle podniosłej tonacji (zob. A Sermon preached in the Second Presbyterian Church, Albany, Sabbath Evening, May 11, 1834, and repeated, by special Request, on the ensuing Tuesday Evening, in the Second Reformed Dutch Church, in Behalf of The Polish Exiles lately arrived in this Country, by W.B. Sprague, D. D. Minister of the Second Presbyterian Church, Albany 1834).

61 Zob. J. Kłaczkow, Protestanckie wydawnictwa prasowe na ziemiach polskich w XIX i pierwszej połowie XX wieku, Toruń 2008. 
Zdolności poetyckie Jakubowskiego i jego melancholia szły w innym kierunku: ku kunsztownej formie i umiarowi w wyrażaniu spraw ostatecznych. Może dlatego wyczuwa się we Wspomnieniach polskiego wygnańca raczej wpływ Pieśni Osjana Macphersona, poezji Scotta, sentymentalizmu i preromantyzmu. Istotna tematycznie jest inspiracja ukraińska, podolska, wschodnio-kresowa: od zainteresowania się Jakubowskiego mowami Stanisława Orzechowskiego ${ }^{62}$ po przekłady na angielski wierszy Tymona Zaborowskiego i Maurycego Gosławskiego ${ }^{63}$.

Również kulturowa geografia tej książeczki jest bogata: obejmuje Litwę i Wilno, Krzemieniec i Wołyń, Podole, polską Ukrainę, Kraków z Małopolską, a także Warszawę z Mazowszem, którym przeciwstawia się stale Rosję z jej otchłanią zesłań, jaką jest tu Syberia.

Jako poeta Jakubowski reprezentuje osobny, preparnasistowski nurt liryki czarnoromantycznej ze szkoły ukraińskiej. Już w 1973 roku Maślanka z dużą przenikliwością zauważył: „Jest on, by tak rzec, poetą konstruktywistą, wypowiada się chętnie w gatunkach wymagających znacznej dyscypliny słowa, jak sonety czy triolety" ${ }^{64}$. To właśnie upodobanie do kunsztownej formy, powrót do wzorców klasycystycznych przy równoczesnym akcentowaniu tonacji pesymistycznej i problematyki egzystencjalnej nazywam tu parnasizującymi skłonnościami liryka. W tym wymiarze istotnie jego wiersze zapowiadają poezję Młodej Polski ${ }^{65}$. Jako prozaik bliski jest w Polskich kochankach czy Majorze Aleksandrze (fragment niepublikowanej powieści, w zbiorach Biblioteki Polskiej w Paryżu) wzorcom wzniosłej prozy sentymentalnej i preromantycznej. Natomiast jako całość Wspomnienia polskiego wygnańca to interesujący przykład czarnoromantycznej ukrainofilii, zapisanej w formie eseju.

Ostatecznie Jakubowski jawi się jako pisarz osobny. To rzeczywiście, jak by sam powiedział, inny kwiat stepowy: ciemny w kolorach, ale subtelnie wielokształtny, kunsztowny, z odrobiną orientalnego uroku (nawiązania do czasów walk z Turcją...) i kozackiego umiłowania wolności. Do Jakubowskiego mogę więc nie bez pewnej swobody odnieść słowa, jakie zapisał on

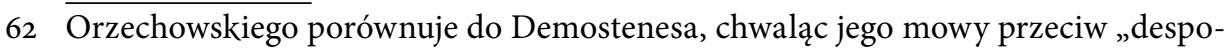
tyzmowi Rzymu” (A.A. Jakubowski, Historyczny szkic o oświacie w Polsce, w: tegoż, Wspomnienia..., s. 82). Kolejny to przejaw sympatii Jakubowskiego do protestantyzmu, choć sam Orzechowski przeszedł w końcu na pozycje kontrreformacyjne.

63 Por. J. Lyszczyna, Pielgrzym w kraju rozkoszy. O poezji Konstantego Gaszyńskiego, Katowice 2000; tegoż, Twórczość poetycka Maurycego Gosławskiego, Katowice 1994; T. Zaborowski, Zdobycie Kijowa, Kraków 2003.

64 J. Maślanka, Wstęp, w: A.A. Jakubowski, Poezje, s. XXXVII-XXXVIII.

65 Tamże, s. XXIII. 
o Kozakach: „Jako że wiedli oni życie tak dzikie i nosili [w piersiach] dzikie uczucia, umiłowanie wolności stało się wśród nich powszechne [...]”66.

Jakubowski był dziki - jako człowiek, był też melancholijny i kunsztowny - jako poeta, owładnięty przez wspominanie - jako eseista. Słowem: reprezentował estetykę czarnego romantyzmu w jego osobliwej, jednostkowej i niepowtarzalnej wersji. W odmianie własnej, szczególnie oryginalnej. Jak jego tragiczne życie.

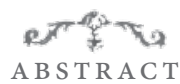

\title{
Black Romanticism of August Antoni Jakubowski
}

The subject of the article is a model of literature which belongs to the mainstream of Black Romanticism developed in the works by August Antoni Jakubowski (1816-1837), an illegitimate son of an eminent Romantic poet - Antoni Malczewski (1793-1826). Deported through Austria to the United States of America, Jakubowski, in his book titled The Remembrances of a Polish Exile, published in 1835, created an original version of Black Romanticism, combining the experiences of pessimism, existential despair with the awareness of a historical and aesthetic Romantic, the co-founder of Polish essay.

\author{
KEYWOR D S \\ August Antoni Jakubowski, Black Romanticism, \\ exile lyricism, essay, Parnassianism, \\ Existentialism
}

66 A.A. Jakubowski, Dodatek, s. 101. I znów mamy tu cechy stereotypu kulturowego Kozaka. Zob.: E. Feliksiak, Ukraina w „Marii” Antoniego Malczewskiego; J. Ławski, Tragiczna i utracona - Ukraina w liryce Augusta Antoniego Jakubowskiego; A. Witlib, Pierwiastki ukraińskie w twórczości Tymona Jakubowskiego; M. Kwapiszewski, Ukraina Zenona Fisza; A. Bracki, Folklor ukraiński w pracach Antoniego Marcinkowskiego - typy, gatunki, tematy, w: „Szkoła ukraińska” w romantyzmie polskim. Szkice polsko-ukraińskie, pod red. S. Makowskiego, U. Makowskiej, M. Nesteruk, Warszawa 2012. 